\title{
TIME AND ITS INDETERMINACY IN ROMAN INGARDEN'S CONCEPT OF THE LITERARY WORK OF ART
}

\section{CHARLENE ELSBY}

PhD in Philosophy, Adjunct Professor. University of Ottawa.

ON K1N 6N5 Ottawa, Canada.

E-mail: celsby@gmail.com

The time of the literary work of art is a schematized aspect of the represented objectivities of the literary work. Roman Ingarden's analysis of the time of the literary work extends upon Husserl's phenomenology of time consciousness but nevertheless remains consistent with it, insofar as within a literary work as well as actuality, an objective time or literary objective time is constituted from an experience of temporal objects (or in the case of the work of art, represented objectivities). The time of the literary work of art is experienced through its represented objectivities and depends on an already existent concept of objective time. (We conceive of the time of the literary work of art as a variant of actual time.) The time of the literary work, however, gains an indeterminacy, as the author of the literary work is able to manipulate our experience of time within the literary work by predicting how the reader will concretize its events, characters, and objects with respect to time. I use Alain Robbe-Grillet's representation of the centipede in La Jalousie as an example of the possible manipulations of time, explicable through Ingarden's analysis of time in the literary work of art.

Key words: Ingarden, literature, indeterminacy, time consciousness, schematized aspects, concretization.

(C) CHARLENE ELSBY, 2020 


\section{ВРЕМЯ И ЕГО НЕОПРЕДЕЛЕННОСТЬ \\ В ТЕОРИИ ЛИТЕРАТУРНОГО ПРОИЗВЕДЕНИЯ \\ РОМАНА ИНГАРДЕНА}

\section{ШАРЛИН ЭЛСБИ}

Доктор философии, адъюнкт-профессор.

Университет Оттавы.

ON K1N 6N5 Оттава, Канада.

E-mail: celsby@gmail.com

Время литературного произведения является схематизированы аспектом наглядным образом представленных объективностей литературного произведения. Проводимый Романом Ингарденом анализ времени литературного произведения выходит за пределы гуссерлевской феноменологии сознания времени, но, тем не менее, следует ей, поскольку и в литературном произведении, и в действительности, объективное время или же объективное время литературы конституируется на основе опыта временных объектов (или, в случае с произведением искусства, представленных объективностей). Время литературного произведения искусства переживается через его представленные объективности и зависит от уже существующей концепции объективного времени. (Мы рассматриваем время литературного произведения как вариант реального времени). Время литературного произведения, однако, приобретает неопределенность, так как автор литературного произведения способен манипулировать нашим опытом времени внутри литературного произведения, предугадывая, как читатель будет конкретизировать события, характеры и объекты по отношению ко времени. Я использую представление сороконожки в «Ревности» Алена Роб-Грийе как пример возможных манипуляций со временем, которые можно объяснить при помощи ингарденовского анализа времени литературного произведения искусства.

Ключевые слова: Ингарден, литература, неопределенность, сознание времени, схематизированные наглядные образы, конкретизация.

\section{INTRODUCTION}

Time in the literary work of art is, according to Roman Ingarden, surprisingly similar to actual time. Time is apparent to and conceived of by the reader of a literary work of art in a similar way to how time is apparent to and conceived of in actuality. The temporality of represented objectivities appears as a schematized aspect of those represented objectivities, the timeline of characters and events fulfilled by the reader in a concretization of the work, differing from the mode of cognition of temporality more general in degree, not in kind. On the other hand, implicit in Ingarden's writing on the temporal progression of literary works of art, is the assertion of a form of consciousness suited to fictional objects, i.e., a mode of cognition that conforms to the presentation of the fictional, rather than actual, persons, objects, and sequences of 
events that define the literary work of art as what it is-a stratified structure through which literary objects become in some way cognized by the reader. We are left to speculate on the exact relation between the cognition of literary objects and actual objects. For example, when we encounter redness in the universe, we categorize it among the possible objects of consciousness accessible by sight, made possible by sense organs. As a quality of a represented object within the literary work of art, on the other hand, the mode of cognition by which we are aware of such things as redness becomes dependent upon, but irreducible to, prior experience of redness in actuality-and the sense in which an experience of redness as represented in the literary work of art is "visual" is obscure. The cognition of literary redness is dependent upon perception, but it is not a perception, if by "perception" we mean only the reception of sensory data.

The temporal aspect of a work of art is similarly dependent upon but irreducible to the experience of temporal objects in actuality - that is, the experience from which our idea of time comes to be elucidated. "Time," considered in itself as an object of cognition, is always somewhat schematized. In the literary work of art, it is more so. In The Cognition of the Literary Work of Art, Ingarden develops a theory of how the reader becomes cognizant of the work of art, both with respect to its temporal aspects (the temporal existence of its objects) and also with respect to the temporality of the reader, whose concretization of the literary work of art results in the aesthetic object. Ingarden proposes a dual awareness of the literary work of art, experienced as it is, in its reading (or listening), as a diachronous object and as a synchronous object, of which we are aware through what Husserl would call a "glancing ray." The difference between these two cognitions is that the former is a temporal experience itself-an experience of an object with duration where the experience itself takes time, whereas the latter is an experience of an object with duration as if in an instant, e.g., in the case where someone mentions The Metamorphosis, and I am for a moment aware of the literary work of art to which the title refers without, however, running through the contents of the work. (Of course, according to Ingarden, there is no such thing as a minimum unit of time, for as he repeatedly points out, this concept is a fiction imposed upon psychologists by the mathematical-physicalistic theories of time.)

An important conclusion that I take away from Ingarden's assertions on the nature of time in the literary work of art is that, while Ingarden admits an analogy between spatiality and temporality, he still denies the contemporary (to him) view that time is both (1) reducible to something atomic, in the sense that he denies that there is some smallest bit of time which might be summed to constitute experience; and (2) he contradicts the views of the analytic metaphysicians who in the early $20^{\text {th }}$ 
century proposed removing time from verbs ${ }^{1}$. Ingarden, on the other hand, retains the temporality of verbs (predicates) proposed by Aristotle in De Interpretatione and does so by integrating the reader's temporality into the cognition of the literary work of art. That is to say, for Ingarden, we do not need to perform a complex calculation between the time of utterance and the time of cognition in order to determine the temporality of a sentence ultimately leading to the abolition of time. Instead, we take into account the temporality of the reader's concretization of the literary work of art and define the aesthetic object as contemporary to the reader (assuming that the reader is successfully able to concretize the literary work of art $)^{2}$.

That is to say, when the author of the literary work of art uses present tense, the aesthetic object is contemporary to the reader's cognition of it. If the author uses past tense, the aesthetic object is conceived of as past. (While we might be tempted to equivocate the aesthetic object with the reader's concretization of the work, these terms are not equivalent for Ingarden.) $)^{3}$ These assertions may not seem revolutionary when stated this simply, but they do imply the retention of Aristotelian notions of temporality and its expression in language, and this retention provides an important counterpoint to the fashionable views of the time. To illustrate the theory of time I am attributing to Roman Ingarden, I analyze a limit case of the objectification of time within a literary work of art-the disjunct time of La Jalousie by Alain Robbe-Grillet ${ }^{4}$.

1 E.g., J.M.E. McTaggart, whose "Unreality of Time" proposed that the only way to resolved contradictions in our conception of time would be to propose a non-temporal series for ordering events (McTaggart, 1908).

2 The exception would be dead works of art.

3 The concretization of a literary work of art is a necessary precondition for the cognition of an aesthetic object, but not sufficient. As Jeff Mitscherling explains, "Concretization refers to the 'filling out' of that which is given only schematically in the work," but such a concretization does not yet constitute an aesthetic object. The aesthetic object is the object of an aesthetic experience. Mitscherling refers to Ingarden, at LWA 372: "It is not the concretization itself which is the aesthetic object, but rather the literary work of art taken precisely as it is expressed in a concretization in which it achieves its full incarnation." The concretization is not yet the fully incarnated aesthetic object. (Mitscherling, 1997, 160, fn. 13) Ingarden differentiates between the concretization and the aesthetic object in The Cognition of the Literary Work of Art, with a helpful example: "For we must basically leave the block of marble behind in a peculiar way, we must forget it to a certain extent, in order to achieve the unfolding and the free continuation of the aesthetic experience, in which the Venus would not merely be constituted but also felt as beautiful." That is to say, he aesthetic object only arises as the content of an aesthetic experience-when the Venus is felt as beautiful (Ingarden, 1973b, 178).

4 The fact that Ingarden's analyses might be applied to this work of art along with so many others never examined by Ingarden himself confirms their accuracy. See also the analyses in Jeff Mitscherling's Roman Ingarden's Ontology and Aesthetics of James Joyce's The Dead and Edgar Allan Poe's 


\section{THE STRUCTURE OF THE LITERARY WORK IN GENERAL}

In The Literary Work of Art, Roman Ingarden conceives of the work of art as a heterogeneous, stratified structure-a polyphonic harmony.

The fundamental stratum of the work of art is its material, i.e., the book, its pages, the bits of ink on the page, or the individual syllables of a reading. I say that the material stratum is fundamental to the work of art, because the work of art (itself not a material object) is ontologically dependent on its material. As Anita Szczepańska elucidates, the work of art has two ontological foundations, one being its material and the other being the creative act through which the work of art is realized. (This differentiates the work of art from other intentional objects, as it has this aspect of material existence in which it is preserved and is therefore not as ephemeral as some other objects for consciousness $)^{5}$.

The words represent ideal meaning units, and the ideal meaning units are combined to form higher order meaning units-phrases, sentences, paragraphs, etc. Thus the stratum of meaning units includes not only words corresponding to represented objects but also the situation implied by their combination - word order and sentence structure, grammatical structures and the author's manipulation of them. The ideal meaning units function together according to some formula determined by the author in order to conjure for the reader represented objectivities - the subjects and objects which I, as reader, conceive of as existing within the fictional world, the fictional world itself, and its reality as far as it extends. As Jeff Mitscherling writes, "if we read that a person is sitting in a room, the potential stock of the word meanings leads us to 'place' this room in a building, and to regard this building as surrounded by a more comprehensive ontic sphere extending far beyond its walls" (Mitscherling, 1997, 136).

In addition, there are "schematized aspects" to the literary work of art-aspects of the represented world that are not given to the reader, but are schematized as necessary aspects of the represented world. For instance, if an author describes a rep-

The Raven. Mitscherling's analysis, like mine, "serves to verify further Ingarden's conception of the literary work of art” (Mitscherling, 1997, 152).

5 Szczepańska writes: “The specific character of this ontological situation, compared to that of purely intentional and not preservable objects, lies in the fact that works of art rely not on a single but on two different autonomous subjects, one of them being an act, creative or perceptive, the other a material object enabling their 'embodiment' and preservation. The part played by these two ontological foundations may be summarized as follows: the material, existential foundations are the basis of the deurability of the work of art, which makes these foundations more important than the acts of perception; the latter, however, are of a creative or co-creative nature and so are more important in their own right" (Szczepańska, 1989, 25). 
resented object as a human, these details are conceived of as "schematized." In The Cognition of the Literary Work of Art, Ingarden uses Consul Buddenbrook's eyes (from Thomas Mann's 1901 novel Buddenbrooks) as an example, saying, "We know implicitly, through context and by the fact that he is a human being and has not lost his eyes, that his eyes are of some color; but we do not know which." Jeff Mitscherling provides an excellent summary of the schematized aspect and its role as one of the strata of the literary work of art:

When consciousness attends to (or "intends") a particular object, it is usually the case that only some of the "aspects" of that object are presented immediately to consciousness, and these aspects are said to be either fulfilled or unfulfilled. For example, when we look at a table from above, the table presents us with the aspect of "table-top" and "table-bottom," and the former is fulfilled while the latter remains unfulfilled. When we look at the table from beneath, the former (table-top) aspect is unfulfilled and the latter (table-bottom) is fulfilled. A similar situation obtains in the case of the literary work of art, but here the reader is often forced to fulfill for herself many of those aspects that are presented by the author as unfulfilled, and she does so with regard to those aspects that are presented more fully, i.e. as fulfilled. The latter provide the reader with a direction to follow in her intentional activity of fulfilling these unfulfilled aspects, which are said to have been presented as 'schematized.' This intentional activity of the fulfillment of schematized aspects is a central component of the general activity of 'concretization.' As no character, for example, can ever be exhaustively presented by an author-no character, that is to say, can ever be portrayed as fully and completely determined-the manner in which this concretization is to proceed can be only schematically determined by the literary work through its stratum of these schematized aspects. (Mitscherling, 2010, 143-144, fn. 10)

Time, within the literary work of art, is especially schematized, for it is always assumed but hardly ever specified that the world of the literary work of art proceeds in a temporal fashion in much the same way as our real world does. We assume that the objects represented are temporal objects-also that they exist in space. While there is always a temporal progression implied just by the fact that the words of the novel are placed in sequence, their duration or temporality is even less explicit than many other aspects. Ingarden writes,

To a certain extent we choose a formal temporal schema for the events which are reported and try, in a purely conceptual way, to fit them into it, although it is never actually filled by them. The schema in such a case has many gaps, for two reasons: first, because the events are missing in many phases (at least for us, to whom they are completely unknown); and second, because we do not construct it conceptually in all its phases. Only when we think it necessary for some reason do we bridge those gaps mentally by making mental connections among the phases of the schematic time with the help of relations and dependencies among the facts related to us. (Ingarden, 1973a, 106-107) 
That is to say, while we are usually tasked with filling in gaps in all represented objectivities, the temporality of those objectivities is left even more to the imagination, for the author is much more likely to write, "His hair was brown," than she is to write, "His hair was brown at 2:07 in afternoon on that Thursday in late May, and it would be for quite some time." While there are schematized aspects to the sentence, "His hair was brown," (such as the fact that there exists a human male who has not lost his hair), the temporality we infer from the sentence is even less explicit. We assume that the human male has duration, as does his hair, but we must fill in these durations, for they are but schematized aspects. We assume, for instance, that the hair does not outlast the man, that it may change color over the course of his lifetime, and that the human male probably has 100 years on him at best, but these things are never stated.

\section{THE MODE OF COGNITION BEST SUITED TO REPRESENTED OBJECTIVITIES}

Ingarden purposefully defines the mode of consciousness of the literary work of art in the broadest way possible, calling it "cognition." The fact of the matter is, this general definition is required in order for whatever mode of consciousness it is to be able to conceive of the varied objects within the literary work of art. For every object there is, there is a mode of consciousness suited to it. This we know from our everyday experience of actualities.

The Husserlian conception of the intentional act specifies a hylomorphic structure to any intentional act, whose aspects (separable only in thought, i.e., consciousness is always consciousness of) are a form of consciousness and an intentional object. The content of an intentional act is its object, and the form of consciousness is particularly suited to that object. This is to say no more than that we are conscious of the blueness of the sky in a different manner than the manner in which we are conscious of grandma's birthday. The way in which we are conscious of an object is suited to the object itself. But while Husserl conflates the intentional object and the content of an intentional act (for he eventually, i.e., in his later works, sees no difference between the world and the lived world), Ingarden distinguishes between the intentional object and the content of consciousness in The Literary Work of Art. The content is the object intended-the table, real, wooden, and the source of many bruises to the shins. The "intentional object" is the same table considered as an object of consciousness-the table as cognized (Ingarden, 1973a, 118). The table as content is not an intentional table; the table as intentional object is.

The concretization of the literary work of art results in the possibility of an aesthetic object for an aesthetic consciousness. But in order to conceive of the literary 
work of art as an aesthetic object, we must conceive first of its represented objectivities. These are the objects represented in the literary work-Thanos, his evil plot, and the valiant efforts of the Avengers to stymy his intentions. The point is, the represented objectivities are of all sorts. In order to conceive of the objects of the literary work of art-and the fact of the matter is, that we are conscious of them-we must be capable of a multitude of forms of literary consciousness, corresponding to but not equivalent to the forms of consciousness by which we are conscious of actual objects. There is a way in which we must conceive of the literary blue as a presently existing quality of a literary object, but this is not perception through a sense organ. Nor is it through retention.

The temporality of a represented object, too, is conceived. There is a literal sense in which the represented objectivities within a literary work of art, the consciousness of which constitute the formation of an aesthetic object, become present to the reader. If they are represented to the reader as if in the past (i.e., if the author uses the past tense), then they are present to the reader analogously to any other past event. But if the represented object is written about in the present, then its quasi-existence is posited in a quasi-judgment on the part of the reader that lends present existence to the object.

Ingarden's analysis here rests on the concept of "temporal distance." If an author writes of something as if in the past, then we conceive of it as temporally distance from our present situation. That is, for instance, if a writer starts a book saying, "A long, long time ago, in a land far, far away..." then we conceive of the events as happening in the past. They are, on the other hand, presently concretized by the reader, but concretized as temporally distant. The past lends an element of necessity to the events, for the past is done and gone and cannot be altered. On the other hand, while Ingarden doesn't go into it, we can imagine a future time in which things are not as necessary but still possible. The represented objectivities of the future are still potentialities, and therefore more malleable or broader in scope. They are plucked from among the things that could happen, rather than the things that could have, the latter category being much smaller than the former.

The author may also choose to represent something in the present, and in that case the temporal distance between the reader and the object is reduced to zero. While the author is long dead, the reader may yet read, and concretize the objects represented by the author as presently existing. This is the case, for instance, in the example Ingarden gives us of a Rilke poem, which reads: "Death is great. / We are his / with laughing mouth. / When we think ourselves in the midst of life, / he dares to weep / in the midst of us" (Ingarden, 1973b, 136). The reading of this poem in no way trans- 
ports us to the past, such that we might conceive of death as imminent to the long dead author at some point in the far past. Rather, we read this and are aware that death is presently great.

\section{THE TIME OF THE VERB}

In this section, I will elucidate temporality as a schematized aspect of all verbs. The argument contemporary to Ingarden's writing would be that not all verbs indicate temporality. This view is meant to contradict the so-called temporalism of Aristotle and all those who admit the distinction between past, present and future. Relative to this debate, I will place Ingarden squarely among the temporalists, and I will argue that his reasoning is sound.

The conception of verbs against which Ingarden is arguing claims to be atemporal. That is to say, when we read the sentence, "Death is great," we are meant, according to these theorists, to interpret the predicate to be irrespective of time. Death is always great, or eternally great, or even better, great in such way that isn't expressible within time at all. We call these people "detensers," for they wish to remove the present tense from verbs such as "is," and to hold that statements like "Humans are mortal" are not temporal statements at all, but atemporal statements about facts irrespective of time ${ }^{6}$. Thus, they conceive of a verb as if it had no time at all, contrary to Aristotle's definition of the $\dot{\rho} \tilde{\eta} \mu \alpha$ in De Interpretatione as that "what additionally signifies time, no part of it being significant separately; and it is a sign of things said of something else" (Aristotle, 1984, 16b6-7).

6 Jeremy Butterfield is a contemporary detenser and proclaims that the defining premise of the movement is the belief that, "the present is an epistemological/subjective notion reflecting our limited knowledge at any time of a temporally extended reality" (Butterfield, 1984, 161) I believe that the movement began with J. M.E. McTaggart's “The Unreality of Time”, written shortly after Einstein's publication of the theory of special relativity. According to McTaggart, to conceive of the same event as all of past, present and future is contradictory, and to take recourse in the claim that the same event is all of past, present and future at different times just assumes the premise one aims to prove-and the only solution is to declare the unreality of time. His argument against the temporality of time results in the attempt to remove time from logical statements-the detensing movement. It is not clear that Ingarden was aware of this movement, only that his views are directly contradictory to it. Helena Eilstein summarizes in "Against Detensers": "An old and persisting metaphysical dispute focuses on the problem whether the concept of happening or [synonymously] becoming of events pertains to the very way of existing of the universe; in other words, whether the way of existing of the universe consists in the incessant succession of temporal triads whose members-that is, the respective Past, Present and Future-objectively differ from one another" (Eilstein, 2002, 93). 
The difference between these views is that Ingarden, contrary to other theorists, recognizes that the literary work of art (which may be as small as a single sentence) is only actualized in its concretization by the reader. The literary work of art exists as a potentiality, as does the sentence, "Death is great," only to be actualized by the cognitive processes of a conscious subject. In the attempt to objectify language, the detensers have removed time from the sentence, but they have also denied what the sentence is. What it is, is something depending on a further concretization. That concretization places something expressed in the present tense in the present. And that is just to say that when we read the sentence, "Death is great," we become conscious of a represented objectivity, death, which is great, and most relevantly, it is something that is great now.

The motivation for removing temporality from the statement is to make language appear more objective, as if it is a thing removed from the human community that formed it. But that is to remove the communicative aspect from language. The telos of a linguistic formation is to communicate, i.e., to call to consciousness a represented object present to the consciousness of the author at the time of writing. Without its reception, language does not perform its communicative function; it does not fulfill its telos and therefore is not what it is. Language that does not communicate is analogous to an eye that does not see-it is not an eye at all, but some bit of flesh that resembles an eye. That is just to say that language is symbolic, and it is essentially symbolic. If it were the case that language existed that did not call anything to consciousness for the reader, we would say that language is dead.

The most general claim to infer from this analysis is that there is no represented objectivity that we conceive of as existing outside of time. Objects, as we know them, are temporal, as are we. Objects exist in time, and we experience them as such, even when their temporality is schematized. If we do in fact experience an object as existing outside of time, it is only through abstracting from a present experience that it is possible, i.e., we take a temporal object and remove time from it.

\section{THE TIME OF THE WORK}

The literary work of art is temporal in a sense not determined by the temporality of its materiality or the creative act of its author. At every level we discover a sequentiality to the work of art significant of its temporality. (The graphic marks are presented sequentially, word order matters, the represented objectivities follow a coherent timeline, etc.) The particular sequencing of words determines, for the reader, the objects represented. That is to say, the same content, ordered differently, results 
in the consciousness of different represented objects. The fact that the material and ideal strata of the literary work of art are presented in an order determines that it is an object with duration. Ingarden says in a footnote, in order to explain why he is using terms that he will only later explain, "We cannot say everything at once" (Ingarden, 1973b, 7). In much the same way, it is impossible to experience the entirety of a work of art at once-at least in the first encounter. For before one can refer to Crime and Punishment as a unity, one must experience it over time through a reading-which necessarily takes place over time. Catherine Kietz makes this a key feature of literary experience, saying, "The whole work cannot be apprehended in a single moment, but only in temporal phases" (Kietz, 2015, 53) ${ }^{7}$. Experience of a literary work of art is temporal, but it is not merely because of such experience that the work of art is temporal. We look at a long book or a short book and correlate its length with the time it will take to experience it - the number of words on a page has temporal significance. Some books are a quick read while others are a slog, depending on the verbiage and sentence complexity. All of these descriptions indicate the work's temporality (a temporality besides the time represented through the events of the book). After the fact, we may think back to the work as a whole, such as Crime and Punishment, but nevertheless, we must recognize that to become conscious of Crime and Punishment as an aesthetic object is to have lived through experiencing it over time.

Thus, there are two ways to access the literary work of art, one as a synchronous unified object only synthesized after the fact of its experience, but nevertheless recognizing it as a diachronous object that must be experienced over time. Ingarden gives us an example of such an experience: World War I.

\begin{abstract}
There are two main ways of remembering past processes: either we apprehend a whole temporal interval and what happened in it from the standpoint of our actual present in a single act of remembering, all at once (for example, as we call to mind in one act the long period of World War I); or else we transport ourselves in memory back to the beginning of the period in question and, in the process of remembering, progress as it were simultaneously with the remembered period by calling to mind the successive events and processes phase by phase. (Ingarden, 1973b, 110)
\end{abstract}

Even when we cast a glancing ray to the object of consciousness, "World War I," we recognize that the object itself took place over an extended period of time, i.e., it is an object with duration. The literary work of art, too, is necessarily an extended object. Its objects and events are presented in sequence. It has a length, and its length

7 This aspect of the literary experience is the topic of Kietz's paper. (It's not just a throwaway sentence). 
corresponds to a time over which it must be experienced. Its sentences lie there one before the other, and the "before" refers not only to an ordering on a page, but an intended order of reading that will take place over time.

We can conceive of the literary object as extended but not in time, but again, this is to abstract time from an object that is essentially temporal.

\section{THE TIME OF THE WORLD OF THE WORK}

The objective time of the book, by which I mean the general "time" of the literary work of art, in which all of its represented objectivities are conceived of as existing, appears to us as itself an object of consciousness ${ }^{8}$. I submit that I am conscious of the time of the characters of book as if it were the time of another person-it's time that belongs to someone (though that someone may be indeterminate) and which provides the basis according to which I order things chronologically. (And I will order things chronologically, because that's what I do). Unlike my present times, literary times appear as subject to my will, just as Husserl describes non-present times. That is to say, I can run my consciousness through the events of a novel at a slower or faster pace, or I can cast a "glancing ray" at some time within the novel, such that my consciousness of it itself seems to take no time at all. (These are the various modes according to which I access past times or, to use Husserl's terms, “The Modes of Accomplishment of Reproduction" (Husserl, 1964, 59-60).) Non-present times are malleable, just as Husserl described in his 1905 lectures on time consciousness, and I add, so too are the fictional times of the literary work of art. As an object of my consciousness, literary time is malleable in a way that my present time is not, but which is similar to how I remember other times or conceive of the times of other people. Edith Stein examines, as analogous cases, my conceptions of my past self, my future self, an imagined self and an other (Stein, 1989, 8-11). I take this as given and in addition specify that every conceived self is temporal.

8 I am using the phrase, "objective time" as does Husserl in the lectures on time consciousness, to refer to the one and unified time that we abstract from our experience of temporality (for we access temporality through our experience of temporal objects), and put forth as an object for consciousness. "Objective time" is what we mean when we colloquially say "time"-we make the assumption that we share a common temporality, and we use that temporally to undergird and fix individual temporal objects and our experiences. Husserl says, "Finally, what is constituted here as valid, Objective being [Sein] is the one infinite Objective time in which all things and events-material things with the physical properties, minds with their mental states-have their definite temporal positions which can be measured by chronometers" (Husserl, 1964, 26). 
If we accept Ingarden's account of time as a schematized aspect of the represented objectivities of a literary work of art, alternate times come to be possible objects for cognition (as I argue later, in the case of the nouveau roman). This is possible because of our capacity to experience the fictional other in much the same way that I experience the actual other. I take the fulfilled aspects of their temporality and I fill in the unfulfilled aspects of their existence, constituting a person whose temporal experience seems analogous to my own. In order to describe our experience of the time of a fictional person, it's useful to point to Stein's description of empathy, and the apt analogy between the experience of other persons and the experience of ourselves at other times. She starts the third section of Chapter II of her dissertation, "The Essence of Acts of Empathy," saying, "There is a well known analogy between acts of empathy and acts in which our own experiences are given non-primordially" (Stein, 1989, 8). She proceeds to discuss the relevant commonalities between empathic experiences and memory, expectation and fantasy. My analysis builds on this by introducing an empathy for fantasized persons, i.e., the characters of fiction. Whereas the subject of phantasy is, for both Stein and Husserl, a fantasized self, it's not too far of a stretch to specify that in addition, we can have an experience of a fantasized other-the fictional character. And these fantasized others are temporal. The empathic experience of reading a literary text, I argue, places the reader in the sort of "neutral present" that Stein attributes to the experience of fantasy. She states,

The fantasized experiences are in contrast with memory because they are not given as a representation of actual experiences but as the non-primordial form of present experiences. This "present" does not indicate a present of objective time by an experienced present which in this case can only be objectified in a 'neutral' present of fantasized time. (Stein, 1989, 9)

That is to say, whereas the forms of consciousness of memory and expectation are consciously located in the past and the future, respectively, the experience of fantasy introduced a neutral, and non-primordial present. There is a secondary present, but it is not mine. This sort of present is the present in which we may locate the events of the novel we are currently reading. We recognize that the time of the book may not coincide with our own-it may even be a period piece, or otherwise give explicit reference to a time that isn't coincident with our present ${ }^{9}$. The objective time of the novel itself

9 It is also important to recognize that the time of the literary work of art need not be conceived of as the time of any one represented character, i.e., while it is possible to empathically consider the time of other subjects, the time of the literary work of art is not, consequently, subjective. Ingarden makes a particular case in his own discussion of Lipps with regard to impersonal statements, saying, “T. Lipps asserts that in each sentence we read, a speaking - in his words, an 'ideal' - I is given. This 
is perhaps anchored by an actual time, for instance if we are told that the novel takes place in 1957 or if we infer such a time from a description of the setting, but the time in which the novel takes place is not identical to world time. A fictional 1957 and a worldly 1957 are not identical (and all we need to observe in order to confirm a multitude of temporalities within literature is that there are events in the fictional 1957 that did not take place in our own 1957, i.e., we need only admit that fiction is possible). Nonetheless, I am conscious of the time of the literary work of art as another kind of present-a neutral present, not located anywhere within my own objective time.

Alain Robbe-Grillet's book La Jalousie (Robbe-Grillet, 1957) is a nouveau roman whose innovations include but are not limited to an alternative presentation of time. I argue that the nouveau roman alters our consciousness of an objective time within the world of the book, our conception of temporal objects within the book, and ultimately reveals a literary objective time that cannot be conceived of as the time of either the character or the reader, but reflects a temporality of the work of art, which is (as Ingarden described) a stratified structure comprised of material, ideal and intentional elements. There is a literary temporality that we conceive of as analogous to our own time, a literary time in which the events and characters of the novel subsist (their consciousnesses and their objects). But in addition, there is within the nouveau roman a frenetic, recursive and discontinuous time, where the temporal objects (e.g., the centipede and its demise at the hands of Franck) still appear as temporal unities, but which belongs to the book neither in virtue of its created world (the world of the book) nor the world in which it was created (our world). And this is just what we mean when someone asks us, "Where are you in the book?" And I respond, "Franck just killed the centipede for the fourth time."

\section{FRANCK AND THE CENTIPEDE}

In La Jalousie, the killing of the centipede repeats, and this is what distinguishes the objective time that I constitute from my own temporal experiences from the literary objective time that I constitute from an empathic experience of the neutral

view, however, strikes me as being not quite correct" (Lipps, 1903, 497 (as cited in Ingarden, 1973a, 206)). It is not the case that the literary work of art's narration be pinned to any one subjectivity, for the work of art may include such impersonal statements that are not necessarily the expressions of a narrator, whom we might conceive of as a represented objectivity. Ingarden writes, "In other words, if the meaning contents of the sentences or the circumstances under which they appear do not indicate the author as the narrator, the entire work is, so to speak beyond the reach of the author; he himself does not belong to the work as a represented character. It is different when the author represents himself as narrator in the corresponding states of affairs" (Ingarden, 1973a, 207). 
times of the represented objectivities in the novel. When I read the novel, it is as if I am going over the same event multiple times, remembering it this way and that, imagining it from other perspectives, and all the while attempting to attribute numerical identity to the centipede as a temporal object as well as to describe the unique event of its murder. But there are not several events described, and they are not present to my consciousness in the same way as something I may choose to remember or imagine or expect-the content of the intentional act is the same, but placed within a neutral present, and this neutral present has the capacity for repetition that my objective time does not. The experience of repetition defies the form of my present experience of time, in which past impressions recede into the past, constantly replaced by protended realities becoming present and then, too, receding. When we read of other subjectivities within the context of the novel, we conceive of time appearing to them in much the same way as it appears to us, but the events of the novel appear to us neither within our own time nor in the times of its characters, and this is true for any novel. But the nouveau roman actualizes a capacity of literary objective time to become something different from and more than objective time-literary objective time is not an imitation of objective time, realized within a novel. Literary objective time has a capacity that my objective time does not, and it should therefore be conceived of as a distinct object.

My empathic relation with the fictional character allows for me to describe their temporality as subjects along with the objective time that we can infer from their experience. The correlate of their temporal experience is, of course, the temporal object, for all objects within the novel also appear as existing within its non-primordial time. The literary temporal object appears as existing within the time of the world of the novel. To me, it appears also as malleable; it appears as a present potentiality that could be actualized in a reading at any particular time. That is to say, while temporal objects in my time are conceived of, and retain identity through their modification by a quality of pastness, the literary temporal object achieves neutral temporality. Its temporality is relative to literary objective time, as opposed to worldly objective time (our time). It does not appear to me as present, past, or future relative to my own time, but its time is determined relative to an objective time of the literary world. Relative to the time of the novel, the centipede appears as something that was born, dreamed of crawling up a wall, and met an untimely demise.

The difference between our objective time and the objective time of the literary world that I want to point to in this paper is the capacity for multiple neutral presents to coincide. The repetition of a singular event - the death of the centipede-appears at multiple points within the novel, such that I might be tempted to conceive of it either 
as multiple events or as one event experienced at different times. These are the forms of consciousness that I am used to applying within our own world of objectivities. There are two possible ways of conceiving of the death of the centipede within my own objective time, and both attempts are doomed to fail.

The first would conceive of the centipede and its demise as an intentional object. I may go through the novel and count up five centipede deaths and then attempt to conceive of these events as distinct, in which case there would be five centipedes (five intentional objects) and five deaths. This fails, because killing five centipedes is an experience with which we're all familiar, and we can readily point to the differences between the experience of killing five centipedes and of killing the same centipede five times.

In another futile endeavor, I might apply a notion of identity over time to the centipede, and attribute the variation to subjectivity. I attempt to fit the repeated death of the centipede into a form of consciousness that ascribes a varying subjectivity to the same object. In this attempt, there are no longer five centipedes but one, and its death is multiple because of the various intentional acts applied to it. This would be similar to how I might look at an object in my office from multiple angles (to see if it is arranged properly) over some period of time. This too fails, because our intentional acts are temporal, along with their objects, and there is a temporal distinction between the intentional acts applied to the same object which I might claim are applied to an object that maintains identity over time, but here too there is a relevant distinction. The various intentional acts relative to the centipede's death in the novel are all to take place within the same neutral present, of which I am conscious at several moments.

That is to say, the experience of the death of the centipede within the novel cannot be subsumed under other forms of consciousness with which we are already familiar. It is distinguished because of its temporality-the death of the centipede takes place within a neutral present, and it is possible for multiple neutral presents in a literary objective time to coexist, or be spread out over a period of our own objective time, without contradiction. The same literary time, i.e., the temporal consciousness of its characters and its temporal objects, can subsist in multiple neutral presents that, within our temporal experience as the reader, appear not as distinct and simultaneous events, but as within one literary time, and thus indicates that literary time consciousness does not hold to the same rules as does our objective time-specifically, linearity and the stark distinction between past and future events. The neutral present of the literary work of art is neither atemporal, nor is it an imitation of objective time; it's something distinct.

That is to say, when I conceive of the fictional time of La Jalousie, it is not the time of any of the characters in particular, nor is it the time of the temporal objects that ap- 
pear and reappear to me (as a constant potential object for consciousness). There is a time that I have constituted as existing within the world in which those characters live. I conceive of an objective time of the novel in which I, as reader, chronologically order the novel's events, and in which I conceive of the characters as living. And I conceive also of an objective time that I constitute based on the author's presentation of events which, in the nouveau roman, is a time of which no character in the novel is aware, but I as a reader am, although it is not my objective time. There is an additional temporality to the literary work of art that cannot be attributed to the experienced time of any of the characters in the novel, which appear to me imaginary others through an empathic relation with the literary character. There is a time that is reserved for the reader precisely because of their distance from the world of the book, but which is also nowhere in the reader's actual world. It belongs to the novel and yet is not of the world of the novel, nor is it of ours, and it is not analogous to our consciousness of objective time, as its properties diverge significantly from the properties of our time.

\section{CONCLUSION}

As Husserl describes phenomenological time consciousness, our consciousness of objective time is achieved through our experience of temporal objects. When Ingarden applies this phenomenology to the literary work of art, literary time becomes a schematized aspect of represented objectivities. That is to say, time is an implicit quality we attribute to the represented objects of a literary work of art, and from that schematized aspect we are able to constitute an objective time in which the world of the book takes place. This is an application of how, for Husserl, our concept of "objective time" is constituted from our experience of temporal objects. Husserl says, in The Phenomenology of Internal Time Consciousness:

It is indeed evident that the perception of a temporal Object itself has temporality, that perception of duration itself presupposes duration of perception, and that perception of any temporal configuration whatsoever itself has its temporal form. (Husserl, 1964, 42)

This is to say that the object of consciousness is temporal, and so is consciousness. An objective time is inferred, as that which must undergird any particular temporal experience or temporal object ${ }^{10}$. Husserl takes it as a necessary precondition of

10 At this point we must vehemently object to the idea that Husserl conceives of two sorts of time-one objective and one subjective. While objective time is not perceived (it is abstracted from temporal objects, as the essence of anything is intuited from its instances), it is nevertheless that upon which all of our experience depends. The fact that we can experience time subjectively is only possible if 
temporal objects and temporal consciousness that they all refer to an objective time. All temporal objects, including consciousness, implicitly refer to an objective time in which they are placed. Husserl even goes so far as to claim that a fantasized time must refer to the same objective time, if we are in any way able to conceive of the fantasized time as real. He says, "Even every arbitrarily phantasied time is subject to the requirement that if one is able to think of it as a real time (i.e., as the time of any temporal Object) it must subsist as an interval within the one and unique Objective time" (Husserl, 1964, 96).

There is, therefore, a relevant distinction to be made between fantasized time and the literary objective time that is the object of my analysis. Whereas a fantasized time is one that refers to objective time, which is one and unique, literary objective time presents itself alongside objective time, to question whether it is, in fact, one and unique. In general, my experience of the fictional world is not equivalent to a fantasized world, for a fantasized world refers necessarily to the real world. The world of the literary work of art, on the other hand, does not present itself as grounded within this world. It is an alternate reality with its own time (literary objective time).

This temporality cannot be explained by the temporal existence of the novel in the world, i.e., its temporal existence as a work of art. We may describe the genesis of the novel according to its creation by an author. It comes into existence as a potential object for consciousness, realized by the author and ready to be concretized by the reader. At some point, the novel may lose its cultural relevance. We may no longer be cognizant of the meaning of the novel, as it had been conceived of by the author in their own time. We may gather all of the copies of the novel in a storage locker and then burn the place down, at which point the work of art would exist only in the consciousnesses of its readers who, at some point, will all die and their memories along with them. Thus a literary work of art may be conceived of as having a timeline within

there is a one and same objective time to which we all take recourse to ground any subjective variations. Here I disagree with Kietz's interpretation of Husserl, where she says that Husserl believes we perceive time directly and gives the example of a succession of musical notes. (Kietz, 2015, 54-55) The experience of objective time is similar to the experience of an "I," a comparison Ingarden makes in a 1937 lecture, „Der Mensch und die Zeit“, (published in Polish in 1938). The publication in Polish contains a passage not contained in the Paris lecture and which Półtawski translates in his, "The Problem of Time in the Philosophy of Roman Ingarden." Ingarden writes, “... a contemplation of how my 'I' is constituted for me indeed strongly undermines my belief that I exist as a human being who transcends his actual experiences and his actual present. But at the same time this contemplation is not capable of banishing this belief entirely..." (Półtawski, 2002). In the same way, objective time transcends moments of time and temporal objects, and yet we cannot dismiss it as a fiction constituted by subjectivity. 
the world of the reader and yet, this time is also not identical to the bumpy, jumpy, and anxiety-ridden time of the nouveau roman.

In The Literary Work of Art, Roman Ingarden conceives of the work of art as a heterogeneous, stratified structure. The most basic element of the work of art is its material, i.e., the bits of ink on the page coming together to form words. These words represent ideal meaning units, and the ideal meaning units are combined according to some formula in order to conjure for the reader some represented objectivitiesthe subjects and objects which I, as reader, conceive of as existing within the fictional world. In addition, there are "schematized aspects" to the literary work of art-aspects of the represented world that are not given to the reader, but are nevertheless necessary aspects of the represented world. For instance, if an author describes a represented object as a centipede but does not go on to specify the appearance and number of its legs, these details are conceived of as "schematized"-they are necessary to our conceiving of the centipede as a centipede, and the fulfillment of this expectation is how the centipede comes to be an object for us in the represented world.

There is a literary temporality that we infer to belong to novel and its events. It is possible for an author to describe a particular time within the book, but such a time is necessarily an aspect of the world of the book. There is, therefore, a schematized time that we attribute to the world of the novel that is consistent, linear, forward-moving, and in which all of the events of the novel take place, and it is also the time that I imagine the characters of the novel experience. But this is not the only schematized time of the novel. Whereas this sort of literary time would be constituted as a schematized aspect of the world of the book - the content of the book-the literary objective time I wish to distinguish is a time of the novel's form. In the nouveau roman, at least, we can see the potentiality for another schematized time, which appears to us as a schematized aspect not of the represented objectivities of the novel, but of the book's formanother objective time, in addition to that which we attribute to the book's content.

This other objective time is the literary objective time, and it appears within the schematized aspects of a represented objectivity that appears to us as temporal but which defies being objectivated as within a time analogous to ours. The centipede and its death indicate to us another sort of time, a schematized aspect of the event in its multiple representations. Whereas what we are given is multiple represented objectivities, including the centipede, the napkin, and Franck's murderous intention, we are led to fulfill the unfulfilled aspect of these representations, which is the literary objective time, with its capacity for multiple neutral presents.

That is to say, the time that Robbe-Grillet presents to me is not the time as it appears to Franck as he pulls out his napkin to destroy the terrible, many-legged in- 
truder. The nouveau roman is the vehicle for a time that (1) belongs to the form of the novel, as opposed to its content; (2) is not the time I attribute to the events and characters of the novel (which I can yet describe as an objective time of the world of the novel, and that through which I interpret the temporality of its represented objectivities); (3) is not the time of the novel's existence as a literary work of art in the world; and (4) is significantly differentiated from our objective time with respect to linearity and the capacity for the repetition of numerically identical events. Concurrent with the nouveau roman comes the genesis (in time) of another kind of time, which is literary objective time. Roman Ingarden's assertion that the time of the literary work of art is a schematized aspect of its represented objectivities allows for a variability of literary time that distinguishes it from objective time, while actual objective time provides the foundation for literary time, insofar as it gives us something to vary. The indefiniteness of a schematized aspect (the spots of indeterminacy of a literary work of art, as described by Ingarden) allows for such manipulations.

\section{REFERENCES}

Aristotle. (1984). De Interpretatione (J.L.Ackrill, Trans.). In The Complete Works of Aristotle, Vol.2. Princeton: Princeton UP.

Butterfield, J. (1984). Seeing the Present. Mind: New Series, 93 (370), 161-176.

Eilstein, H. (2002). Against Detensers. In H. Eilstein (Ed.), A Collection of Polish Works on Philosophical Problems of Time and Spacetime (93-125). Dordrecht: Kluwer Academic Publishers.

Husserl, E. (1964). The Phenomenology of Internal Time Consciousness (J. S. Churchill, Trans.). Bloomington: Indiana UP.

Ingarden, R. (1973a). The Literary Work of Art. An Investigation on the Borderlines of Ontology, Logic, and Theory of Literature (G. G. Grabowicz, Trans.). Evanston: Northwestern University Press.

Ingarden, R. (1973b). The Cognition of the Literary Work of Art (R. A. Crowley \& K. R. Olson, Trans.). Evanston: Northwestern University Press.

Kietz, C.(2015). Temporal Conflict in the Reading Experience. In P.F.Bundgaard, \& F. Stjernfelt (Eds.), Investigations Into the Phenomenology of the Ontology of the Work of Art: What are Artworks and How Do We Experience Them? (51-73). Dordrecht: Springer. https://doi.org/10.1007/978-3-319-14090-2_4

McTaggart, J. M.E. (1908). The Unreality of Time. Mind: New Series, 17 (68), 457-474.

Mitscherling, J. (1997). Roman Ingarden's Ontology and Aesthetics. Ottawa: University of Ottawa Press.

Mitscherling, J. (2010). Aesthetic Genesis: The Origin of Consciousness in the Intentional Being of Nature. Lanham: University Press of America.

Półtawski, A. (2002). The Problem of Time in the Philosophy of Roman Ingarden. In H. Eilstein (Ed.), A Collection of Polish Works on Philosophical Problems of Time and Spacetime (137-148). Dordrecht: Kluwer Academic Publishers.

Robbe-Grillet, A. (1957). La Jalousie. Paris: Minuit.

Stein, E. (1989). On the Problem of Empathy (W.Stein, Trans.). Washington, D. C.: ICS Publications. Szczepańska, A. (1989). The Structure of Artworks. In B.Dziemidok, \& P. McCormick (Eds.), On the Aesthetics of Roman Ingarden. Interpretations and Assessments (21-54). Dordrecht: Kluwer Academic Publishers. 